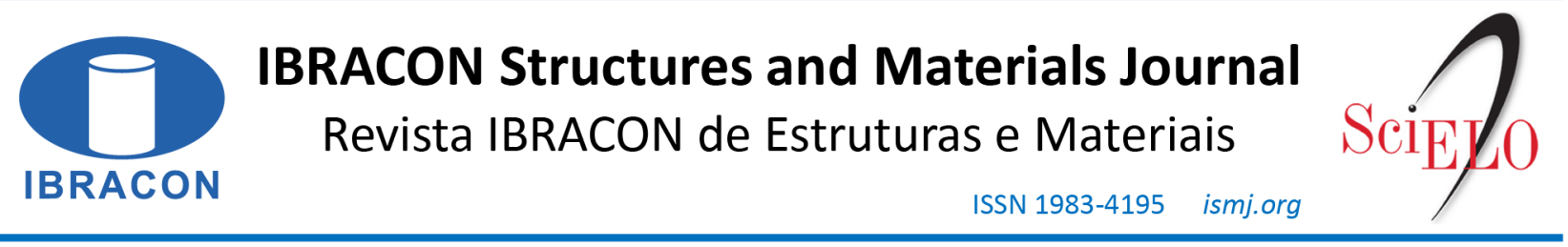

ORIGINAL ARTICLE

\title{
Hardness correlation length in a self-compacting concrete
}

\section{Comprimento de correlação da dureza em um concreto autoadensável}

\author{
Bruna Maria Becker Junges ${ }^{\mathrm{a}}$ \\ Nadine Machado Ficher ${ }^{\mathrm{b}}$ (it) \\ Luis Eduardo Kosteski ${ }^{b}$ \\ Ederli Marangon ${ }^{\mathrm{b}}$
}

\author{
${ }^{a}$ Universidade Federal do Pampa - UNIPAMPA, Alegrete, RS, Brasil

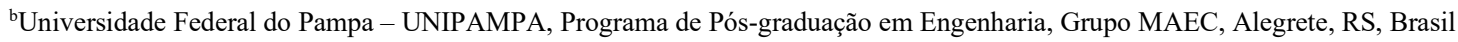

Received 03 May 2018

Accepted 02 October 2019

\begin{abstract}
This paper presents an experimental study of spatial variation of hardness or indentation strength of a selfcompacting concrete. With the pourpose of validation, the comparison between the used methodologies with the values obtained by numerical simulation is presented. The correlation length (Lcor) obtained on the semivariogram using a Gaussian model is similar to the numerically simulated value, especially when the distance between the measurements is less than the sought Lcor. Using sclerometry, it was possible to infer that to find the value of concrete correlation length it is necessary to measure nearby points, at ca. $2 \mathrm{~cm}$ apart. With this scheme, the value of Lcor found is close to the obtained using macro-indentation, a more complex and time-consuming procedure. Finally, for the studied self-compacting concrete, the correlation length is equivalent to a value between 5 to 6 times the maximum aggregate size.
\end{abstract}

Keywords: spatial distribution, self-compacting concrete, hardness, indentation.

\begin{abstract}
Resumo: Neste trabalho apresenta-se um estudo experimental da variação espacial da dureza ou resistência à indentação de um concreto autoadensável. Inicialmente é apresentada a comparação da metodologia utilizada com os valores obtidos por simulação numérica com o intuito de validação da mesma. O comprimento de correlação (Lcor) obtido do semivariograma utilizando o modelo Gaussiano é próximo ao valor simulado numericamente, especialmente quando a distância entre os pontos medidos é menor que o Lcor procurado. Utilizando esclerometria foi possível concluir que para encontrar o valor do comprimento de correlação do concreto é necessário realizar medições em pontos próximos, na ordem de $2 \mathrm{~cm}$. Com esta metodologia, o valor de Lcor encontrado é próximo ao obtido utilizando macro-indentação, procedimento esse mais complexo e demorado. Assim, para o concreto autoadensável em estudo, encontrou-se o comprimento de correlação equivalente a um valor entre 5 a 6 vezes o tamanho máximo do agregado graúdo.
\end{abstract}

Palavras-chave: distribuição espacial, concreto autoadensável, dureza, indentação.

How to cite: B. M. B. Junges, N. M. Ficher, L. E. Kosteski, and E. Marangon, "Hardness correlation length in a self-compacting concrete," Rev. IBRACON Estrut. Mater., vol. 13, no. 4, e13401, 2020, https://doi.org/10.1590/S1983-41952020000400001

\section{INTRODUCTION}

Material behavior is a problem that is under continuous study and, even today, it is a subject that is not yet completely exhausted. Multiscale materials can be considered homogeneous or heterogeneous depending on the level of observation. According to Silva et al. [1], cementitious composites are considered as typical representatives of multiscale materials since they can be treated as homogeneous at the macroscopic level (length scale $\mathrm{cm} \sim \mathrm{m}$ ) and as heterogeneous materials at a more precise level of observation (scale in length $\mathrm{nm} \sim \mathrm{cm}$ ).

This multiscale heterogeneity determines the mechanical performance (stiffness, strength) and degradation (damage, fracture, failure) of cementitious materials [2]. Due to the heterogeneity of the material properties, safety

Corresponding author: Luis Eduardo Kosteski. E-mail: luiskosteski@unipampa.edu.br

Financial support: None.

Conflict of interest: Nothing to declare. 
factors are considered to achieve macroscopic properties with certain safety in engineering design. Current trends in concrete science and engineering seek a better representation of this heterogeneity at various length scales [3].

Classical methods of statistical data analysis generally assume that the realizations of random variables are independent of each other, considering that neighboring observations do not influence each other. Spatial data analysis presents itself as an alternative and/or as a complement to classical data analysis, as this type of analysis considers the correlations between observations [4].

Spatial analysis of data, using geostatistics, has gained momentum since the 1980s in areas other than mining and geology, with great applicability in soil science. This became possible due to the computational ease that made feasible some calculations relatively laborious in this methodology [5]. The applicability and use of geostatistics as a methodology for analyzing data in space or time has been disseminated in various branches of science, involving the areas of social, biological and exact sciences [4].

Local or specific mechanical properties influence the behavior of concrete in its global form, such as its compressive stress, elasticity, creep, and durability, among other factors. The study of the spatial distribution of these properties allows to understand the material behavior at different points on the surface. Following the idea proposed by Constantinides et al. [2], [4], this study can be carried out using a grid of points, in which each point presents the mechanical properties obtained through experimental tests.

Thus, the general objective of this work is to study the spatial distribution of the hardness of a self-compacting concrete and to define a distribution model of the material properties on the analyzed surface, in order to obtain the macroscopic behavior of the material. Geostatistics was used for the spatial analysis of the data, with emphasis on the analysis of the semivariogram for the determination of the spatial dependence of the data. An initial validation through numerical simulation is also presented.

\section{MATERIALS AND EXPERIMENTAL PROGRAM}

In this section, first the phisics properties of the materials used for the production of self-compacting concrete is shown. The characterization of the materials used for the concrete production and composition were performed by Padoin [6]. Afterwards, the sclerometry and macro-indentation tests of self-compacting concrete are described. Finally, the methodology for the spatial analysis of the data is presented.

\subsection{Materials}

For this work, a self-compacting concrete developed by Padoin [6] was used to obtain a characteristic compressive strength (fck) of $25 \mathrm{MPa}$. The water/cement ratio of the concrete was 0.5. Table 1 shows the concrete proportion mixture.

Table 1. Mixture of Self Compacting Concrete.

\begin{tabular}{cc}
\hline Materials & $\mathbf{k g} / \mathbf{m}^{\mathbf{3}}$ \\
\hline Portland Cement & 400 \\
\hline Water & 200 \\
\hline Superplasticizer additive & 2,40 \\
\hline Fine aggregate & 731 \\
\hline Coarse aggregate & 904 \\
\hline
\end{tabular}

Medium river sand and origin basaltic coarse aggregate was used. These materials were obtained in the city of Alegrete - RS, Brazil.

The granulometric composition of the aggregates was performed according to the procedures established by NBR NM 248 [7], with the maximum diameter of the coarse aggregate being $9.5 \mathrm{~mm}$ and the fine aggregate being $2.36 \mathrm{~mm}$.

The determination of the specific mass of the fine aggregate was performed according to procedures described in NBR 9776 [8], obtaining the value of $2.75 \mathrm{~g} / \mathrm{cm}^{3}$. For the coarse aggregate, NBR NM 53 [9] was used to determine the specific mass, resulting in a value of $3.19 \mathrm{~g} / \mathrm{cm}^{3}$. The Brazilian Portland cement used for the mixture was the CP IV-32, manufactured by the company Votoran. Also, the Sika's ViscoCrete ${ }^{\circledR} 5700$ superplasticizer additive was added.

The concrete, in its fresh state, had an average spreading diameter of $665 \mathrm{~mm}$ and the mixture did not present any segregation, ensuring homogeneity, as shown in Figure 1a. The passing ability was measured using the J Ring, U Box 
and V Funnel equipments (according to standard NBR 15823 [10]). The passing ability results were $20 \mathrm{~mm}$ for J Ring and $1.5 \mathrm{~mm}$ for $\mathrm{U}$ box, while the flow time, measured through the $\mathrm{V}$ funnel, was found to be 11 seconds.
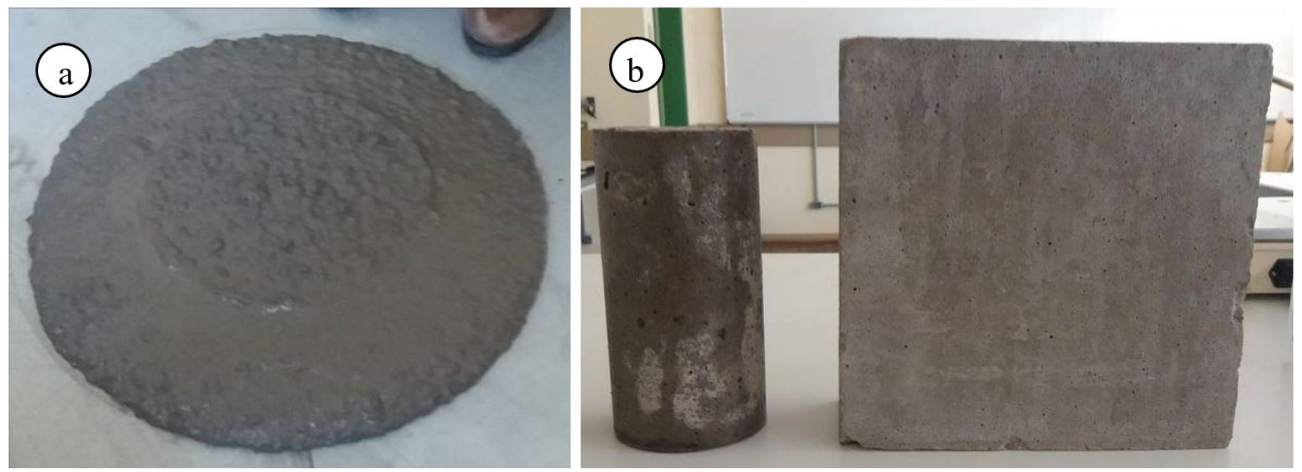

Figure 1. a) Spreading of the concrete in a fresh state and b) types of specimens produced.

Cylindrical specimens of dimensions $(100 \times 200) \mathrm{mm}$, prismatic specimens of $(250 \times 250 \times 100) \mathrm{mm}$ and (200x200x 100) $\mathrm{mm}$ were produced to perform the tests. The specimens were molded and cured as described in NBR 5738 [11]. Figure $1 \mathrm{~b}$ shows the types of specimens produced.

The self-compacting concrete showed, on average (means of 5 specimens), compressive strength at 28 days of $27.67 \mathrm{MPa}$, with a coefficient of variation (CV) of 3.47\%. The tests were performed on an Instron universal machine, with a maximum capacity of $1500 \mathrm{kN}$, following the procedures described in the NBR 5739 standard [12].

\subsection{Sclerometry test}

The Schimidt reflection sclerometer was used, with an impact energy of $0.225 \mathrm{mkg}$ and a tip diameter of $15 \mathrm{~mm}$. The reflection sclerometer was calibrated on the standard anvil, as prescribed by NBR 7584 [13]. Particular care during the measurements was considered to ensure that the surface of the tested concrete was dry, clean and regular.

The test was carried out in two ways: first, by following the recommendation of standard NBR 7584 [13]. The selfcompacting concrete slab used in the test was $(250 \times 250 \times 100) \mathrm{mm}$. The points were initially defined randomically in the specimen, considering the minimum distances between them and the specimen edges, as shown in Figure $2 \mathrm{a}$. Second, by building a regular mesh of lines every $10 \mathrm{~mm}$ on the surface of a (200x200x100) $\mathrm{mm}$ plate. However, as the tip of the sclerometer is $15 \mathrm{~mm}$, the impact points were distributed every $20 \mathrm{~mm}$, to not create overlap measurements. The scheme of the mesh in this case can be identified in Figure $2 b$.

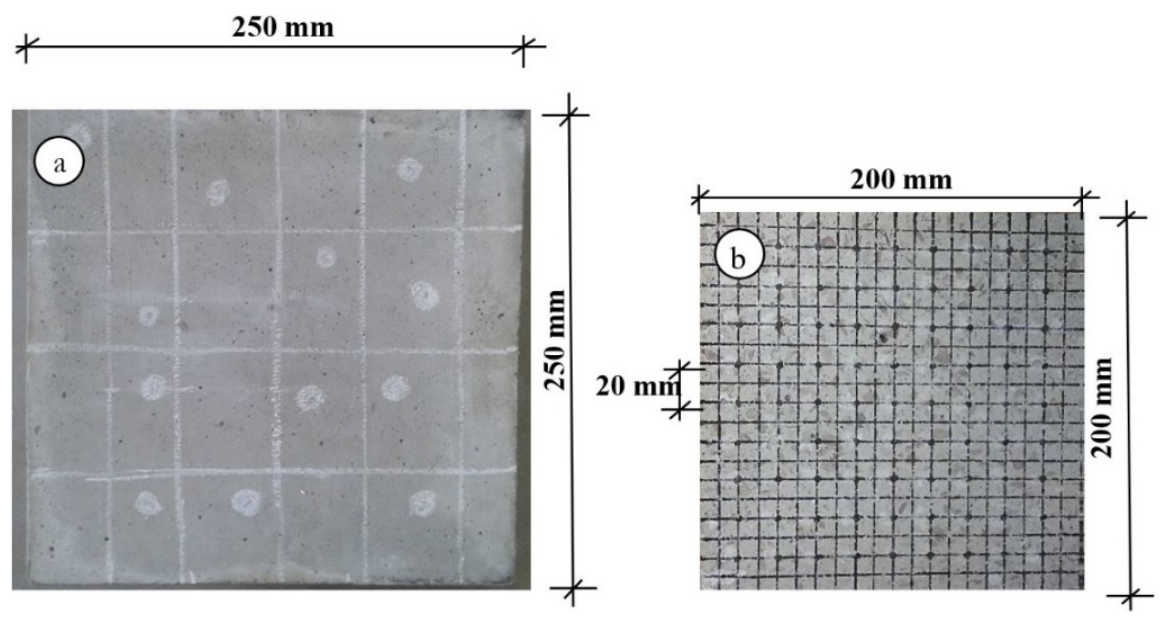

Figure 2. Self-compacting concrete plates used in sclerometry, a) for the analysis based on the NBR 7584 standard [13] and b) for the analysis of indentation with sclerometer on a regular mesh. 


\subsection{Macro-indentation tests}

For the macro-indentation tests, plates with dimensions of (200x200x100) $\mathrm{mm}$ were used, in which $10 \mathrm{~mm}$ distant lines were drawn, forming a regular grid with 361 points, as represented in Figure 3a. The concrete plate with the drawn mesh was placed on the plate of the universal testing machine Shimadzu AGS - X, with maximum capacity of $5 \mathrm{kN}$. The displacement that the material undergoes at each point of the mesh is measured when a compression load of $2000 \mathrm{~N}$ is applied. The contact between the machine and the specimen was made through a steel crew with a semi-spherical head, coupled to the machine load cell. The configuration test is shown in Figure $3 b$.
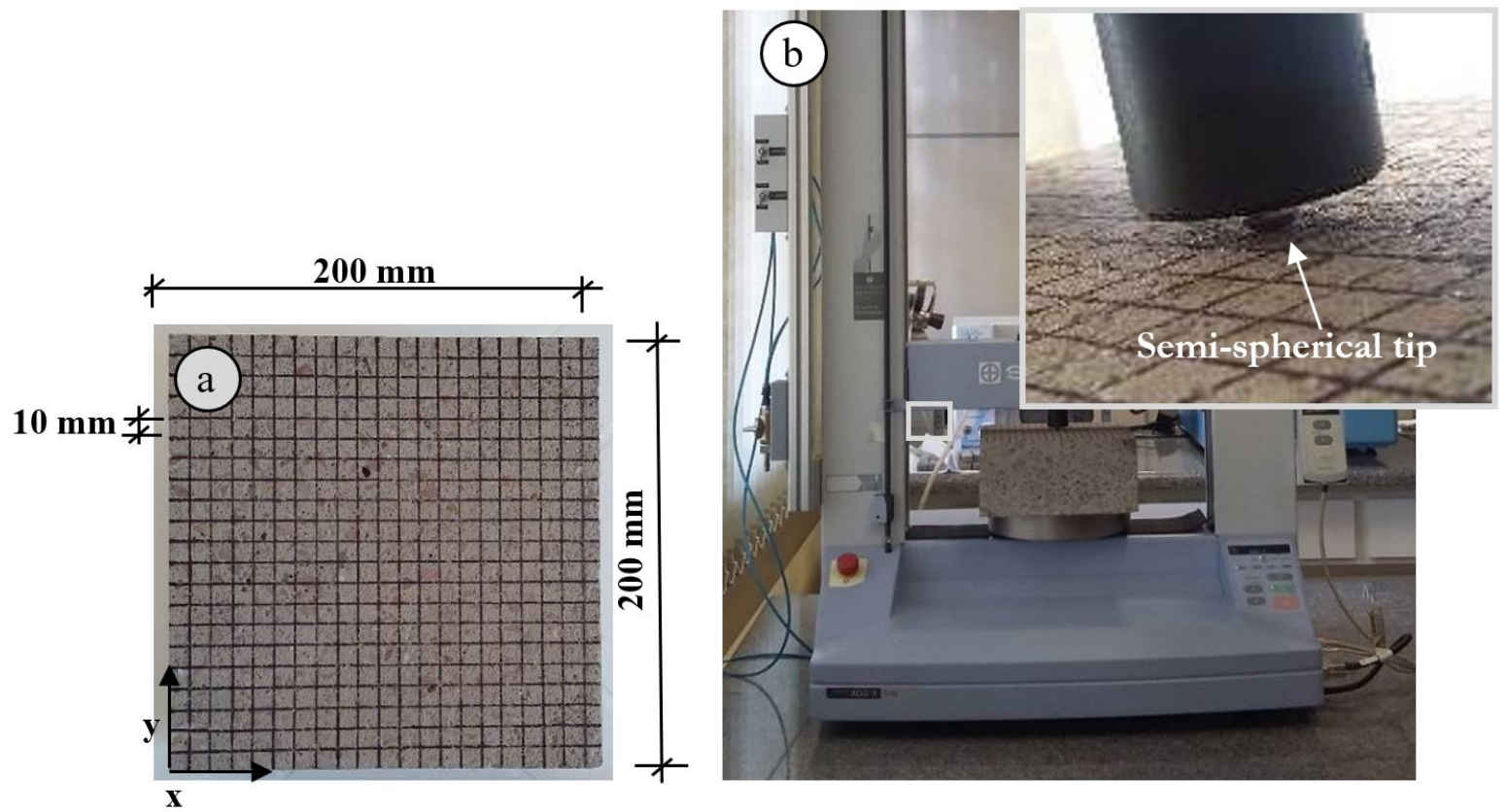

Figure 3. a) Self-compacting concrete plate used in macro-indentation, b) configuration of the test and detail of the indenter.

\subsection{Spatial an alysis of data}

In order to obtain smoother curves in the representation of the spatial distribution of the data, an interpolation by cubic splines was used, both in the Matlab software and in the ArcGis software. In addition, geostatistical data analysis was carried out using semivariograms in the ArcGis software. The semivariograms were modeled using the extension Geostatistical Analyst, with the standard configuration of the ArcGis software. The software generates the semivariograms by means of Kriging interpolation, and supplies the range parameter. Finally, the Gaussian model was used.

\section{RESULTS AND DISCUSSIONS}

First, the validation of the methodology used by numerical simulation is presented and discussed. In addition, experimental data and spatial analysis of data related to the sclerometry and macro-indentation tests, performed on self-compacting concrete, are presented.

\subsection{Validation of the methodology used by numerical simulation}

In order to validate the methodology used, the values of correlation length (Lcor) numerically simulated were also measured and analized with the semivariogram.

This verification was based on the proposal of Shinozuka and Deodatis [14], which aims to make the numerical discretization of the correlation length size of a simulated random field independent. This idea is used to introduce variability in the material, for the lattice discrete elements method (LDEM), as explained in [15]-[18]. In this methodology, the domain (3D) is divided into prismatic regions that have correlation lengths as sides, which may be 
different in the three Cartesian directions (Lcorx, Lcory, Lcorz). At the vertices of these prisms are the poles (V1 to V8) and random values are assigned with unrelated probability distributions. Subsequently, a linear three-dimensional interpolation is performed to determine the value of the random field corresponding to each point inside the prism.

Using this methodology in a two-dimensional state, pseudo-random values with Weibul type II distribution are simulated through an algorithm implemented in Matlab and the programming used in the LDEM method (see Puglia et al. [18]).

First, a two-dimensional random field with Weibull type II distribution was simulated, with mean 1, coefficient of variation (CV) $30 \%$ and correlation length (Lcor) in both directions equal to 1 . In Figure 4, the histogram of the values is shown. The average of these simulated values is 0.979 and the $\mathrm{CV}=31.3 \%$, both very close to the initial inputs in the program to simulate the random field.

Using the Matlab software, the data matrix was interpolated and the spatial distribution graph of the data, plotted in Figure 5a, was made. With the simulated data, the Gaussian semivariogram model was generated in the ArcGis software. Figure 5b shows the Gaussian model with the obtained range and nugget effect.

Theoretically, the range of the semivariogram is closely linked to the value of Lcor, however, when setting Lcor $=1$ in the simulation, this range value (1.907 in Figure 5b) was not obtained in the semivariogram. It is interesting to note that, in this case, the semivariogram has an almost constant graph.

Following the same procedure, random fields with Weibull type II distribution with mean $1, \mathrm{CV}=30 \%$, with Lcor correlation lengths equal to 2, 4 and 6 were simulated. In Figure 6, the spatial distribution histograms of the numerical models are shown togheter with the semivariograms of the numerical analyzes carried out with ArcGis, for the three correlation lengths studied. From Figure 6, it is possible to observe that the range of the semivariogram with the Gaussian model approaches the input value (Lcor) given in the simulation.

From the analyses of Figures 5 and 6, it can be seen that when the distance measured between the points is of the order of Lcor, or greater than this value, the semivariogram appears to be constant from the beginning. The range found with ArcGis software present no relation to the correlation length. On the other hand, when the distance between the measured points is less than Lcor, the semivariogram starts to be constant only after the range, a value that corresponds to the simulated correlation length. Also, the smaller the relationship between the distance from the measured points and Lcor, the greater the precision found.

Comparing Figures 5 and 6, it is possible to observe that greater variability is found in the spatial distributions of the data with lower Lcor . Particularly, in Figure 5 there are many peaks and valleys, while in Figure 6, these maximums and minimums are each time more distanced until, with Lcor equal to 6 , the data variation is low.

This way of interpolating the data from the values of the simulated poles present the desired theoretical distribution, using the methodology initially proposed by Shinozuka and Deodatis [14]. However, it is important to note that this interpolation method changes the characteristics of the data set, as shown in the comparisons between the histograms in Figures 4 and 6. The average value is close to the desired value, however, the CV varies distinctively: the variation is greater when a smaller number of poles is used in the interpolation.

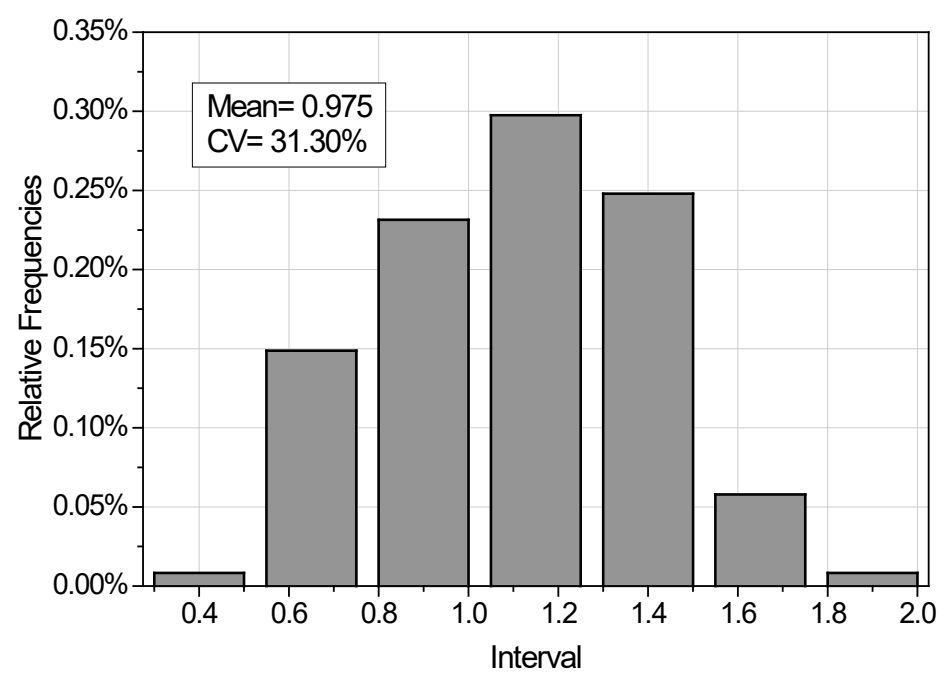

Figure 4. Histogram of the numerical simulation with Lcor $=1$. 
(a)

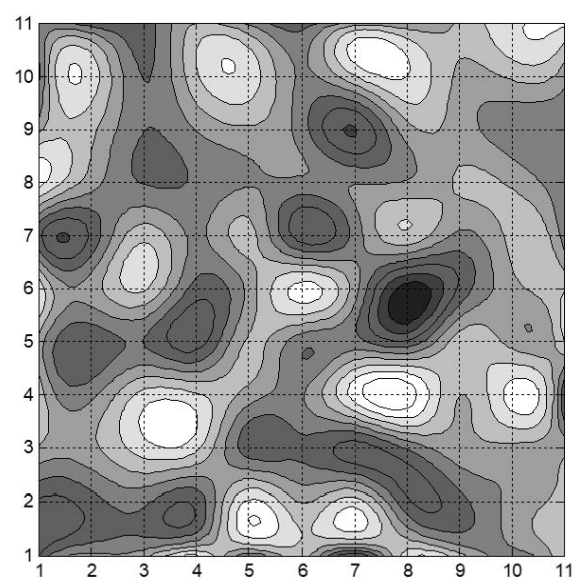

(b)

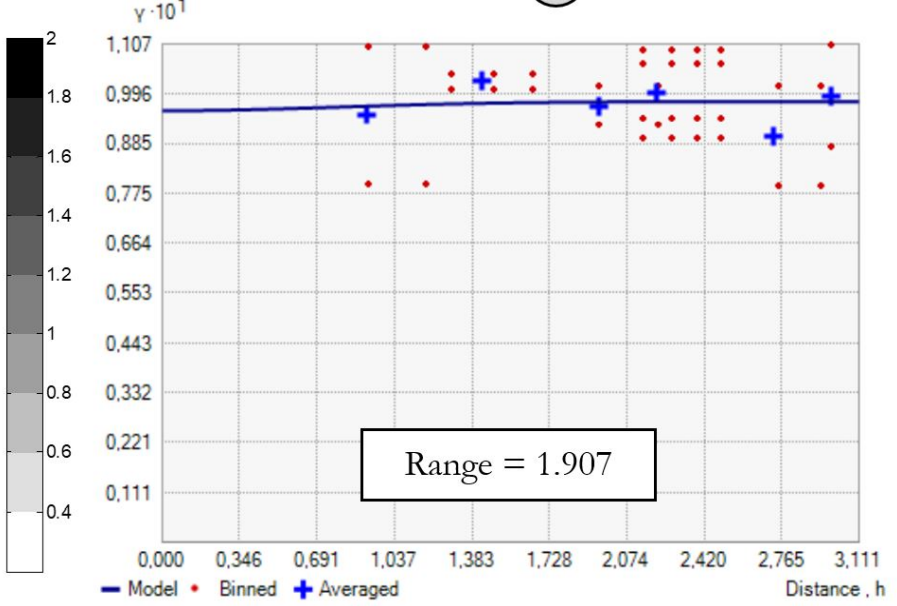

Figure 5. a) Spatial distribution of the numerical simulation with $L c o r=1$, b) Semivariogram obtained with ArcGis analysis of the numerical simulation with Lcor $=1$.
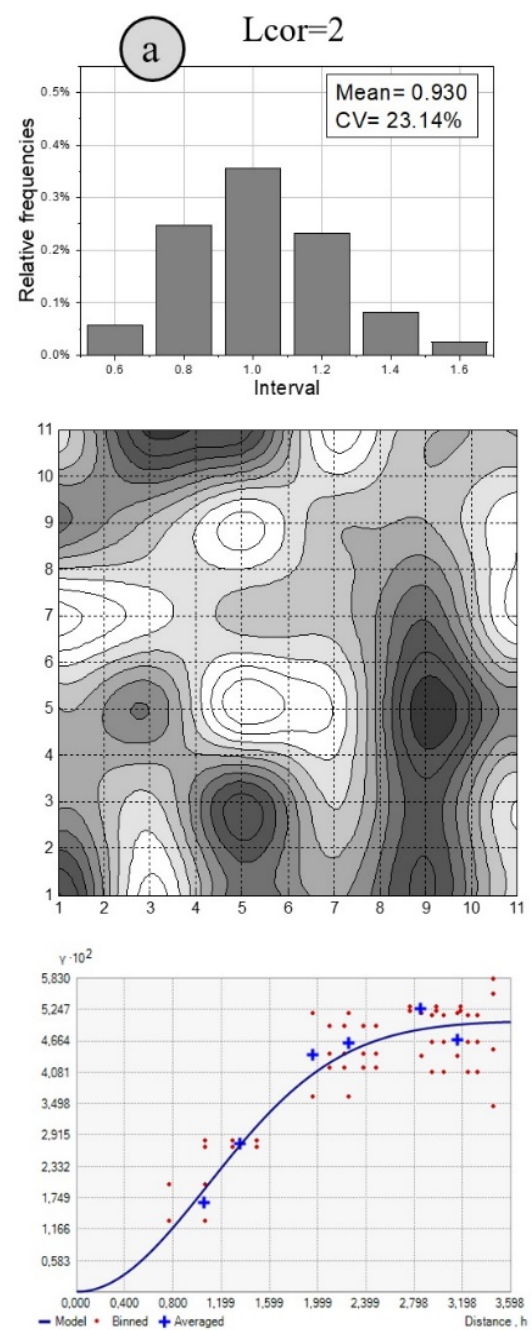

$$
\text { Range }=2.658
$$
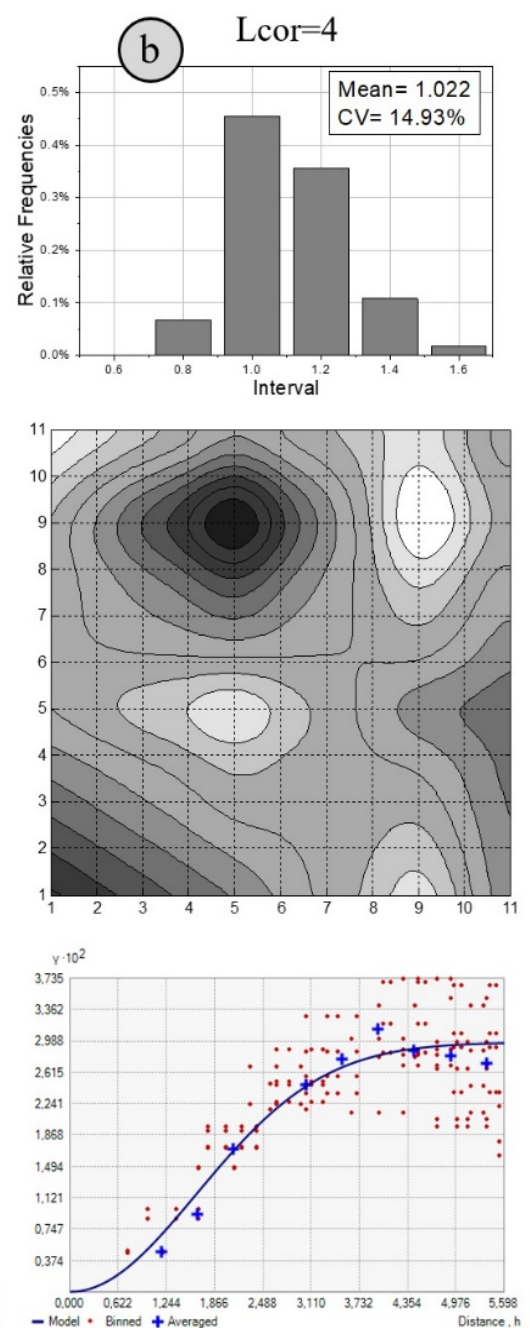

Range $=3.998$
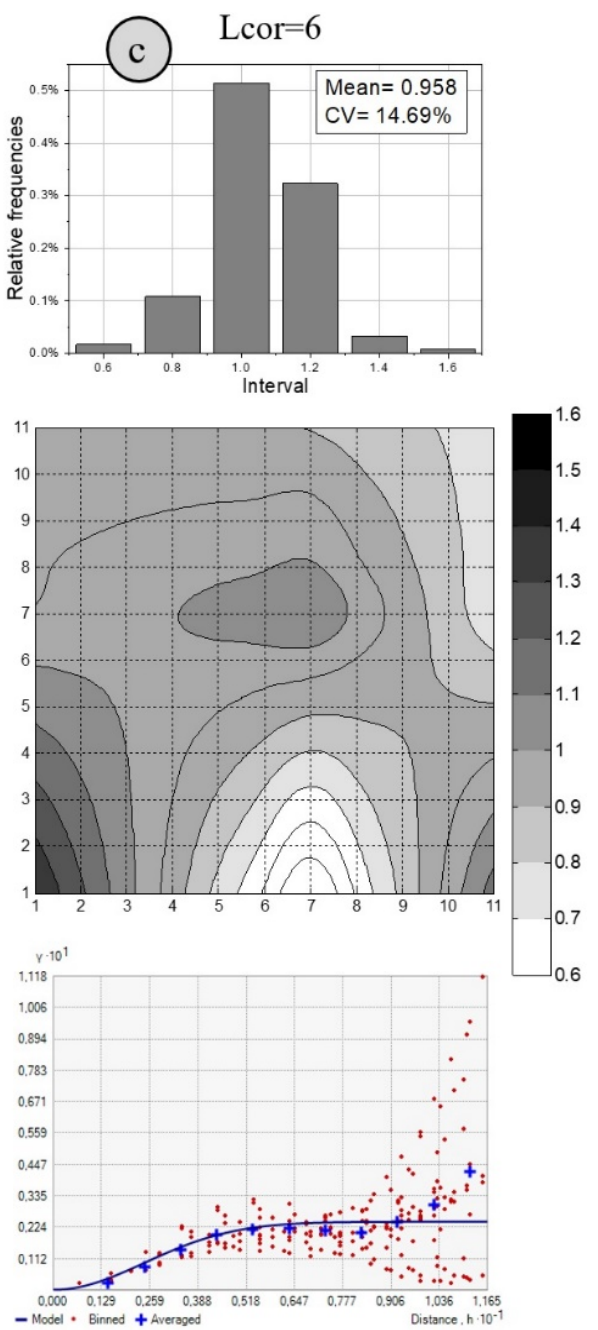

Range $=5.952$

Figure 6. Histogram after the interpolation of the poles, Spatial Distribution and Semivariogram of the numerical simulation with a) $\operatorname{Lcor}=2$, b) $\operatorname{Lcor}=4$ and c) $\mathrm{Lcor}=6$. 


\section{ANALYSIS OF THE CORRELATION LENGTH USING SCLEROMETRY}

\subsection{Analysis based on standard NBR 7584 [13]}

As the main objective of this work is not to evaluate by sclerometry the strength of the concrete, but to analyze the spatial distribution of the data, all the values obtained in the test were kept.

The sclerometric indices $(S I)$ measured in the prismatic specimen $(250 \times 250 \times 100) \mathrm{mm}$, as well as the distances at which the measurements were made, are shown in Table 2. $k$ is the correlation coefficient of sclerometric index found in standard NBR 7584 [13].

Table 2. Results of the Sclerometric index established in NBR 7584 [13].

\begin{tabular}{cccc}
\hline Point $\mathbf{N}^{\mathbf{0}}$ & $\mathbf{x}(\mathbf{c m})$ & $\mathbf{y}(\mathbf{c m})$ & $\boldsymbol{S I}$ \\
\hline 1 & 3.25 & 3.68 & 29 \\
\hline 2 & 13.69 & 3.30 & 34 \\
\hline 3 & 21.87 & 3.10 & 32 \\
\hline 4 & 8.33 & 8.15 & 32 \\
\hline 5 & 19.15 & 8.13 & 34 \\
\hline 6 & 3.76 & 11.91 & 34 \\
\hline 7 & 12.45 & 12.83 & 32 \\
\hline 8 & 18.75 & 12.83 & 38 \\
\hline 9 & 6.48 & 18.64 & 31 \\
\hline 10 & 18.03 & 16.99 & 28 \\
\hline 11 & 22.05 & 18.82 & 30 \\
\hline & 13.87 & 21.44 & 28 \\
\hline & Mean & & 32.00 \\
\hline
\end{tabular}

Using the curve adjusted by [19] and following the Equation 1, in which:

$f_{c}=0.026 S I^{2.044}$

it is possible to obtain the compressive strength for concrete at 28 days of age, which is equal to $27.79 \mathrm{MPa}$; this value is very close to what found in the experimental tests $(27.68 \mathrm{MPa})$.

The data histogram of the sclerometric indexes presented in Table 2 are found in Figure 7a. In Figure 7b, the spatial distribution of the hardness is shown, demostrating great variation of the results. With these data, the semivariogram made in ArcGis with Gaussian model reports a constant function, as shown in Figure 7c. This behavior indicates that the size of the correlation length is smaller than the measurements made (on average $7 \mathrm{~cm}$ ), thus, the Lcor must be less than this value.

\subsection{Sclerometer indentation analysis on a regular mesh}

As explained in section 2.2, the sclerometric index measurements were taken every $2 \mathrm{~cm}$ in both directions (see Figure $2 \mathrm{~b}$ ). Table 3 presents the results obtained in the sclerometry test for the self-compacting concrete plate $(200 \times 200 \times 100) \mathrm{mm}$. It is important to note that the points at the end of the plate were discarded, as they showed distortions in the sclerometric index values. Thus, the average $S I$ was 30.56 , which corresponds to a compressive strength of 28.22 MPa (Equation 1).

In Figure 8a, the histogram for the sclerometric index data presented in Table 3 can be seen. Figure $8 \mathrm{~b}$ shows the data spatial distribution on the plate using splines interpolation in the Matlab software, while in Figure 8c it is possible to see the semivariogram obtained with the ArcGis software for the Gaussian model. When comparing the spatial distribution of the measured hardness according to NBR 7584 [13] (Figure 7b) with Figure 8, it is possible to notice in 
the latter a greater variation of peaks and valleys at closer distances. This indicates that with this methodology, more spatial variability was found than by following the standard normative.
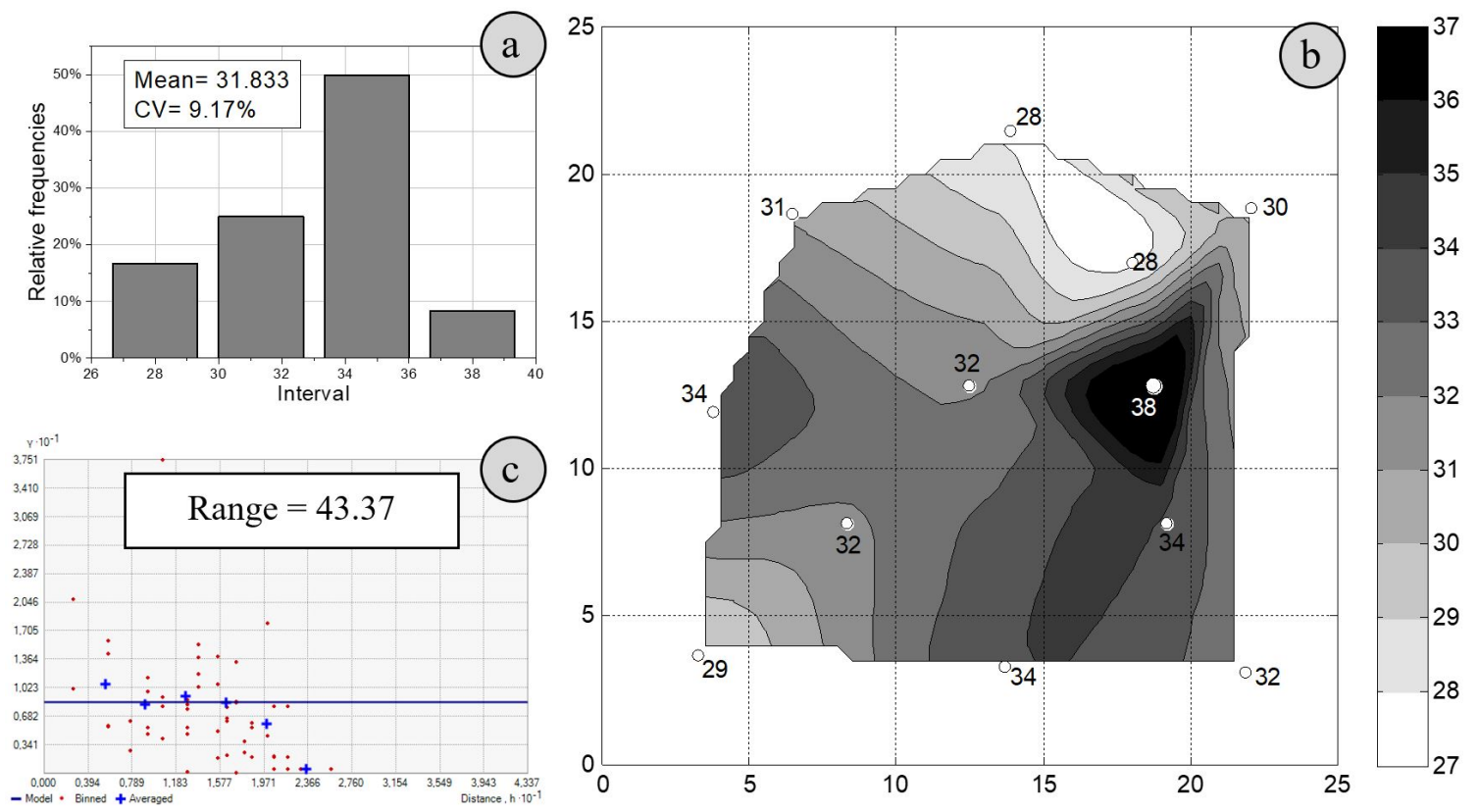

Figure 7. a) Histogram of the sclerometric index data, b) Spatial distribution and c) semivariogram with Gaussian model.

Table 3. Results of the sclerometric index using the regular $2 \mathrm{~cm}$ mesh.

\begin{tabular}{clllllllll}
\hline Coordinates & $\mathbf{x 1}$ & $\mathbf{x 2}$ & $\mathbf{x 3}$ & $\mathbf{x 4}$ & $\mathbf{x 5}$ & $\mathbf{x 6}$ & $\mathbf{x 7}$ & $\mathbf{x 8}$ & $\mathbf{x 9}$ \\
\hline y1 & 23 & 34 & 30 & 32 & 28 & 31 & 32 & 28 \\
\hline y2 & 27 & 27 & 32 & 33 & 30 & 35 & 31 & 30 & 29 \\
\hline y3 & 28 & 29 & 28 & 34 & 33 & 32 & 33 & 28 & 26 \\
\hline y4 & 28 & 31 & 37 & 33 & 37 & 30 & 36 & 30 & 26 \\
\hline y5 & 30 & 37 & 37 & 34 & 32 & 32 & 36 & 32 & 26 \\
\hline y6 & 24 & 30 & 34 & 31 & 32 & 40 & 32 & 34 & 34 \\
\hline y7 & 23 & 32 & 31 & 37 & 35 & 31 & 29 & 28 & 28 \\
\hline y8 & 31 & 29 & 31 & 28 & 26 & 30 & 34 & 28 & 30 \\
\hline y9 & 23 & 26 & 27 & 27 & 30 & 29 & 32 & 25 & 27 \\
\hline
\end{tabular}

In this case, the semivariogram starts to be constant after the range, $4.79 \mathrm{~cm}$, demonstrating that the value used for the measurements, every $2 \mathrm{~cm}$, can be appropriate for this methodology. This range value represents the correlation length for the concrete under study.

\subsection{Macro-indentation test in concrete}

Figure 9a shows a scheme of the self-compacting concrete plate $(200 \times 200 \times 100) \mathrm{mm}$ used in this test, illustrating the displacements and all points of the mesh measured, as described in section 2.3. Figure $9 \mathrm{~b}$ reports the data interpolation by splines, performed in the Matlab software; the measurements at the plate borders were discarded, in order to avoid interference from the boundary conditions. The spatial distribution of the displacements shown in Figure $9 \mathrm{~b}$ has a similar shape to that found by measuring the hardness with the sclerometric index in a $2 \mathrm{~cm}$ mesh (Figure 8b). From these data, a semivariogram model was generated in the ArcGis software, presented in Figure 9c. With this analysis, the correlation length was found to be $5.38 \mathrm{~cm}$. Thus, the value found for Lcor is close to that found with the sclerometer, with a difference of approximately $12 \%$. 

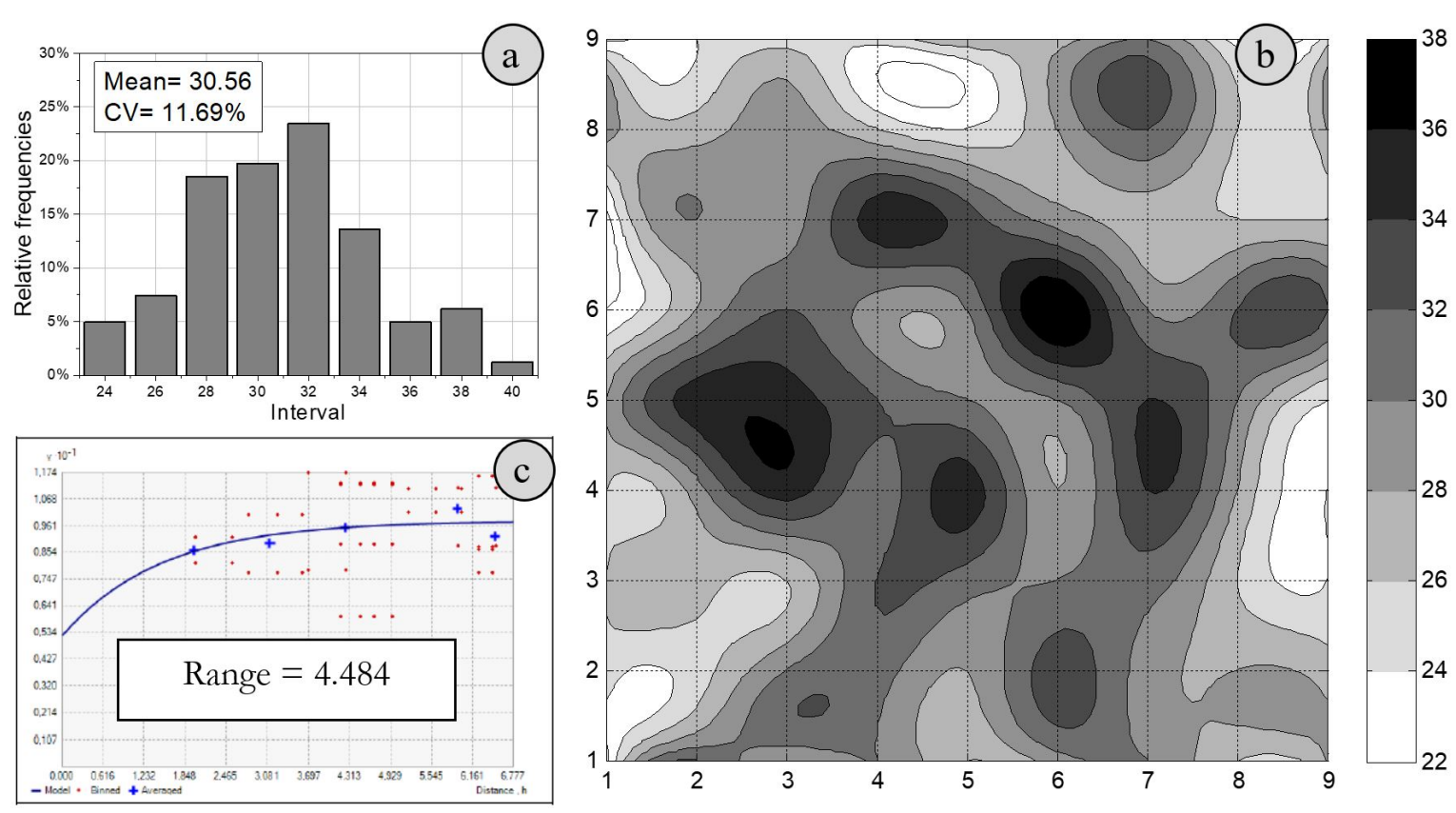

Figure 8. a) Histogram of the sclerometric index data, b) Spatial distribution and c) semivariogram with Gaussian model.
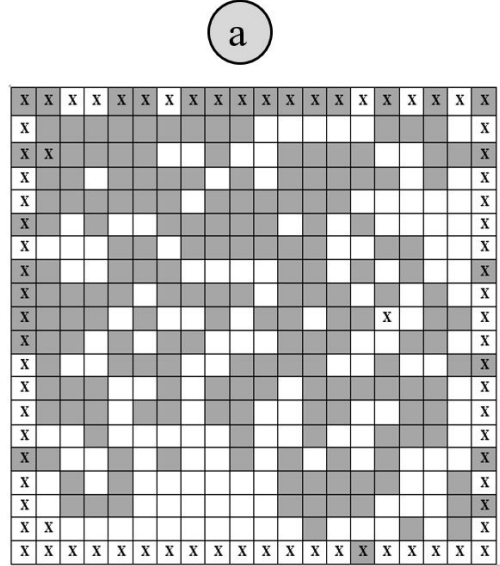
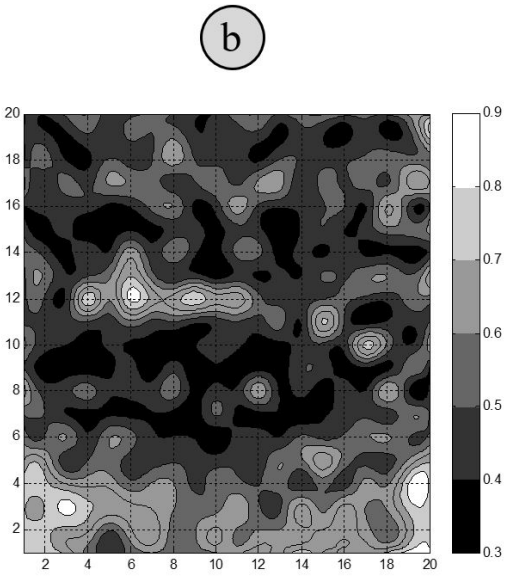
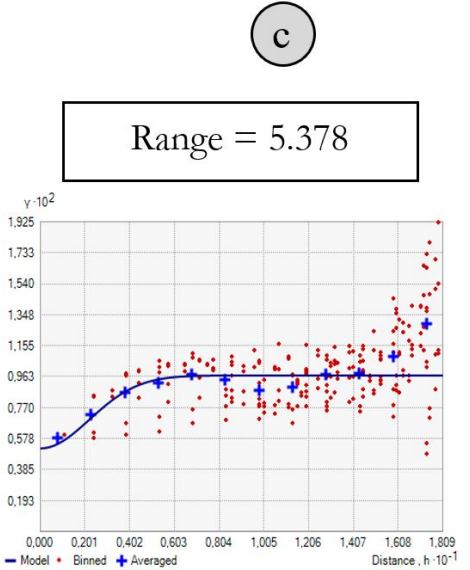

Figure 9. a) Location of points, b) Spline interpolation of data in the Matlab software, c) semivariogram obtained with ArcGis.

\section{CONCLUSIONS}

Based on the results, the following conclusions were inferred:

- When comparing the numerical models, it was possible to observe that when a linear interpolation of the simulated data is performed, the form of the distribution adopted initially is also modified, resulting in an average close to the desired value. However, the CV changes noticeably, as well as the shape of the random distribution. The correlation length obtained from the semivariogram with the ArcGis software using the Gaussian model is close to the simulated value;

- The compressive strength of concrete obtained using the correlation equation [19] with the value of the sclerometric index is close to the value obtained experimentally, showing good consistency of the results;

- The correlation length was not successfully obtained from the analysis of self-compacting concrete with a sclerometer, based on the NBR 7584 standard [13], due to the distance between the measurement points, greater than the material Lcor. When analyzing the points using a $2 \mathrm{~cm}$ mesh, the semivariogram shows that the correlation length is in the order of $4.8 \mathrm{~cm}$; 
- From the semivariogram of the self-compacting concrete macro-indentation analysis it was possible to identify a correlation length of the order of $5.4 \mathrm{~cm}$;

- The correlation lengths (Lcor) measured by both sclerometry and macro indentation are comparable (only $12 \%$ difference). It was also possible to identify that the Lcor for this concrete is approximately 5 to 6 times the maximum size of the coarse aggregate (from 4.75 to $5.70 \mathrm{~cm} ; \phi_{\text {aggregate }}=9.5 \mathrm{~mm}$ ). Finally, we believe that this correlation length for concretes will also be influenced by the mortar content and dimension of the coarse aggregates.

Since the results obtained through macro-indentation and sclerometry are similar, the latter method is more indicated, as it is easy to apply and handle. Still, to obtain more reliable results, we suggest to apply measurements at a distance of maximum $2 \mathrm{~cm}$.

\section{ACKNOWLEDGEMENTS}

The authors are grateful for the support of CNPq and Fapergs. They also thank Unipampa, since resources and laboratories from this institution were used. In particular, the authors would like to thank the Pedra Rosada quarry, which donated the gravel used for the production of concrete.

\section{REFERENCES}

[1] W. R. L. Silva, J. Němeček, and P. Štemberk, "Nanotechnology and Construction: use of nanoindentation measurements to predict macroscale elastic properties of high strength cementitious composites," Rev. IBRACON Estrut. Mater., vol. 5, no. 3, pp. 284-295, 2012, http://dx.doi.org/10.1590/S1983-41952012000300002.

[2] G. Constantinides, F.-J. Ulm, and K. Van Vliet, "On the use of nanoindentation for cementitious materials," Mater. Struct., vol. 36, no. 3, pp. 191-196, 2003, http://dx.doi.org/10.1007/BF02479557.

[3] G. Constantinides, K. S. Ravi Chandran, F. J. Ulm, and K. J. Van Vliet, "Grid indentation analysis of composite microstructure and mechanics: principles and validation," Mater. Sci. Eng. A, vol. 430, no. 1-2, pp. 189-202, 2006, http://dx.doi.org/10.1016/j.msea.2006.05.125.

[4] R. C. Grego and R. S. Vieira, "Variabilidade espacial de propriedades físicas do solo em uma parcela experimental," Rev. Bras. Ciênc. Solo, vol. 29, no. 2, pp. 169-177, 2005, http://dx.doi.org/10.1590/S0100-06832005000200002.

[5] L. R. R. Reis, "Utilização da condutividade elétrica para estabelecimento de zonas de manejo em um latossolo amarelo-escuro,” M.S. thesis, Prog. Pós-grad. Eng. Agr., Univ. Fed. Viçosa, Viçosa, Brasil, 2005.

[6] D. G. Padoin, "Estudo das propriedades mecânicas e físicas de um traço comercial de concreto autoadensável com e sem substituição de cinza de casca de arroz,” M.S. thesis, Prog. Pós-grad. Eng., Univ. Fed. Pampa, Alegrete, Brasil, 2017.

[7] Associação Brasileira de Normas Técnicas, Determinação da Composição Granulométrica, NBR NM 248:2003, 2003.

[8] Associação Brasileira de Normas Técnicas, Agregados - Determinação da Massa Específica de Agregados Miúdos por Meio do Frasco Chapman - Método de Ensaio, NBR 9776, 1988.

[9] Associação Brasileira de Normas Técnicas, Agregado Graúdo - Determinação da Massa Específica, Massa Especifica Aparente e Absorção de Água, NBR NM 53, 2009.

[10] Associação Brasileira de Normas Técnicas, Concreto Autoadensável, Partes 1 a 6, NBR 15823, 2010.

[11] Associação Brasileira de Normas Técnicas, Concreto - Procedimento para Moldagem e Cura de Corpos de Prova, NBR 5738, 2015.

[12] Associação Brasileira de Normas Técnicas, Concreto - Ensaio de Compressao de Corpos de Prova Cilindrico, NBR 5739, 2018.

[13] Associação Brasileira de Normas Técnicas, Concreto Endurecido - Avaliação da Dureza Superficial pelo Esclerômetro de Reflexão - Método de Ensaio, NBR 7584, 2012.

[14] M. Shinozuka and G. Deodatis, "Simulation of multidimensional gaussian stochastic fields by spectral representation," Appl. Mech. Rev., vol. 49, no. 1, pp. 29-53, 1996, http://dx.doi.org/10.1115/1.3101883.

[15] R. D. Rios, “Aplicações do método dos elementos discretos em estruturas de concreto,” Ph.D. dissertation, Univ. Fed. Rio Grande do Sul, Porto Alegre, Brasil, 2002.

[16] L. F. F. Miguel, “Critério constitutivo para o deslizamento com atrito ao longo da falha símica,” Ph.D. dissertation, Esc. Eng., Univ. Fed. Rio Grande do Sul, Porto Alegre, Brasil, 2005.

[17] L. F. F. Miguel, L. F. Fadel Miguel, J. D. Riera, J. Kaminski, and R. C. R. Menezes, "Model uncertainty in the assessment of EPS Wind loads in transmission line design," in Proc. Int. Semin. Model. Identif. Struct. Subj. Dyn. Exc. - Emph. Transmiss. Lin., vol. 1, Z. M. C. Pravia, I. Iturrioz, L. F. F. Miguel, L. F. F. Miguel and R. C. R. Menezes, Eds. UPF Editora, Passo Fundo, 2009, pp. 151173. 
[18] V. B. Puglia, I. Iturrioz, J. D. Riera, and L. Kostesteki, "Random field generation of the material properties in the truss-like discrete elemento method," Mec. Comput. Cilamce-Mecom, vol. XXIX, pp. 6793-6807, Nov 2010.

[19] M. D. Machado, L. D. Shehata, and I. A. E. M. Shehata, "Curvas de correlação para caracterizar concretos usados no Rio de Janeiro por meio de ensaios não destrutivos," Rev. IBRACON Estrut. Mater., vol. 2, no. 2, pp. 100-123, 2009, http://dx.doi.org/10.1590/S1983-41952009000200001.

Author contributions: Bruna Maria Becker Junges: experimental results, numerical analysis. Nadine Machado Ficher: writing, formal analysis. Luis Eduardo Kosteski: conceptualization, methodology, formal analysis, supervision. Ederli Marangon: formal analysis, supervision.

Editors: Paulo Cesar Correia Gomes, José Luiz Antunes de Oliveira e Sousa, Guilherme Aris Parsekian. 